ERNEST ANDRADE, JR.

\title{
Great Britain and the Hawaiian Revolution and Republic, $1893-1898$
}

Captain James Cook's contact with the Hawaiian Islands gave Great Britain a certain pre-eminence in Hawaiian history and attitudes which remained for some time, and was commemorated in the placing of the British Union Jack in Hawai'i's national flag, now the Hawai'i State flag. The British government's disavowal in 1843 of the takeover of Honolulu by a British naval officer and its formal restoration of Hawaiian independence ushered in a period of Hawaiian attachment to Great Britain which made it appear as if Hawai'i would eventually gravitate into Britain's orbit. Actually, however, Hawai'i's ultimate place in the scheme of things was already decided in favor of the United States. American economic and missionary activity in the Islands during the first half of the igth century had already made Hawai'i's absorption by the United States a matter of time. That the Islands were not absorbed earlier was more the result of a disinclination of the United States to do so than anything else. The American declaration of 1854 guaranteeing Hawaiian independence made the Islands in effect an American protectorate and the United States henceforth the determiner of Hawai'i's destiny.

Perhaps because the British recognized the close connection between the United States and the Hawaiian Kingdom, they consistently kept a careful eye out for what might be attempts to bring

Ernest Andrade, Jr. is Professor of History at the University of Colorado at Denver. He is working on a political history of Hawai' $i$ that focusses on Robert $W$. Wilcox.

The Hawaiian Journal of History, vol. 24 (1990) 
that connection even closer. In spite of American disclaimers, annexation of Hawai' $i$ remained a possibility. The British realized that barring an overt effort to simply take the Hawaiian Islandsan unlikely possibility - the most likely circumstance encouraging an American annexation attempt would grow out of instability within Hawai' $i$ itself. During the reigns of the last two Kamehamehas, internal dissension or unrest did not appear, and after the short tragic reign of Lunalilo the Kingdom came to be ruled by David Kalākaua. At first it appeared that Kalākaua's reign would be unusually stable, marked as it was by the famous Reciprocity Treaty of 1875 with the United States. This treaty bound Hawai'i even more firmly to the United States and made an American attempt at annexation more remote than ever.

The optimism of the early years of Kalākaua's reign gave way to increasing concern on the part of both the British and the Americans, as they saw the Hawaiian government under the leadership of Walter Murray Gibson become increasingly unstable through unbridled spending which ran up a large debt and brought corruption among government officials in its wake. Also alarming was the unabashed appeal to factionalism by leaders like Gibson who sought to keep political power by stirring up the Native Hawaiians against the haole (Caucasian) residents, who over the years had come to control the major economic activities of the Kingdom. By early 1887 the situation had reached such a point that haole residents, mostly Americans but including some British, Germans, and other Europeans, were beginning to plot moves to overthrow Gibson and bring Kalakaua under control. ${ }^{1}$

Deeply concerned about these developments was John Hay Wodehouse, Her Britannic Majesty's representative as British Commissioner to the Hawaiian Kingdom. A retired British Army major, Wodehouse arrived in Honolulu in January 1874 to take up his duties, only a month or so before Kalākaua became King. Thereafter Wodehouse worked diligently to protect British interests during a long career which spanned two decades.

In the first half of 1887 , Wodehouse was a witness of the internal unrest which culminated in the revolt of June 30, when the Caucasians rose in arms, forced the dismissal of Gibson, and brought into effect a new constitution which gave them greatly increased 
political power and severely curtailed the powers of the King. As Wodehouse saw events unfolding he was particularly concerned that nothing be done to provoke bloodshed and disorder for fear both of the threat to British lives and property and also the possibility of American intervention and demands for annexation. His actions in 1887 included asking that the British Pacific Squadron send a warship to Honolulu - the ship arrived nearly two weeks after the uprising - and counseling King Kalākaua to submit to the demands of the dissenters to avoid bloodshed. ${ }^{2}$ Wodehouse's actions-arranging for the presence of a British warship and urging the Hawaiian authorities to avoid hasty action-became the pattern of his response to the tumultuous events of the next half decade, and these became policy when the British government invariably approved of his actions.

The Constitution of 1887 did not calm the internal agitation which had characterized the Gibson years; on the contrary, it seemed to increase it. Native Hawaiians were furious at the curtailment of the sovereign's power and were angry at what they considered to be the establishment of political dominance by the Caucasians. Racial tension grew instead of diminishing. Several political figures attempted to take Gibson's place as leader of an anti-haole movement, the most prominent of these being Robert W. Wilcox. A part-Hawaiian who had received military training in Italy, Wilcox led an abortive attempt to replace the 1887 Constitution by taking over the royal palace on July 30, i889. He planned to persuade the King to declare a new constitution. An ever-watchful Wodehouse, who earlier had gotten wind of the Wilcox plot and had tried to get the King to do something about it, ${ }^{3}$ was concerned that no foreign warships would be in port when the uprising was scheduled to occur. Wodehouse had even gone so far as to persuade William Merrill, the American Minister, to keep in port an American cruiser which was to have left earlier. ${ }^{4}$ He did this even though he feared the American government might use a situation of civil war in the Islands to justify an American takeover.

Thanks to quick action by the local haole-led government, the Wilcox uprising was smashed, and the government remained in effective control. But Wilcox became a popular hero among the 
Hawaiians, and the "bayonet constitution" and those who supported it remained an object of hatred and divisiveness in the community. During the next two years events moved to a climax. The haole and the Natives became more polarized after Kalākaua's death in i8gr and the succession to the throne of Lili'uokalani, who was determined to do away with the existing constitution. Her attempt to do so after the distressing and ineffectual session of the legislature of 1892 brought the crisis which led to a rapid and profound change in Hawai' i's political system and in its relations with other countries.

\section{The Revolution of 1893}

Much has been written about the Hawaiian Revolution of 1893 which overthrew the Monarchy and brought Hawai' $i$ very close to annexation to the United States shortly thereafter. The British government's role in those events, however, has not received much attention even though next to the United States Great Britain was most concerned with and affected by the Revolution. The British position was determined long before, during the period briefly summarized above. The view of the government in Whitehall was simply that the situation in the Hawaiian Kingdom should not be allowed to deteriorate into insurrection and civil strife, but if it did, every effort should be made to see to it that Americans in the Islands or in the United States did not use internal disorder as a justification for American annexation. As the man on the spot it was Commissioner Wodehouse who was largely responsible both for making and for carrying out British policy.

As usual, Wodehouse followed closely the events of the last months of $189^{2}$ and of early 1893 . He was sympathetic toward Lili'uokalani, both because of his attachment to the continuation of the Hawaiian Monarchy and because of his belief that she stood against the designs of those Americans in the Islands who wanted annexation to the United States as a permanent solution to the political turmoil in the Islands. He defended her action in dismissing a cabinet she could no longer trust or support and appointing a new one more to her liking on September I, I892. 
He dutifully reported his concern over rumors of a possible takeover by the United States government ${ }^{6}$ and asked that a British warship be stationed in Hawai'i indefinitely to offset an increasing American naval presence at Honolulu. ${ }^{7}$

The Queen's action in unilaterally attempting to proclaim a new constitution just after the adjournment of the legislative session on January 14, 1893 set off the haole reaction which overthrew her and sought immediate annexation to the United States. Wodehouse was appalled at both developments and objected strenuously both to the Hawaiian Provisional Government and to American Minister John L. Stevens, who had ordered American sailors and marines landed from an American warship to maintain order in Honolulu. Wodehouse protested to Minister Stevens concerning this action but was told the leaders of the rebellion had requested the landing of the troops. Furthermore, Stevens indicated the military presence ashore would continue for as long as the Provisional Government decided it should. ${ }^{8}$ Wodehouse was not content with this answer but continued to try to get the troops removed. On January 30, he expressed concern to Sanford B. Dole, President of the Provisional Government, that the men from U.S.S. Boston were still ashore. Noting that newspaper reports were full of stories about the strength of the military forces of the Provisional Government, he professed not to understand why the American troops were needed. "I am therefore constrained to again ask Your Excellency why this Foreign Force is not recalled."9 The next day Dole replied. He did not reply in detail to Wodehouse's letter, saying only that the American forces must remain for the time being for "the general protection of life and property." 10

Nothing more could be done. By now Wodehouse knew that all the other foreign government representatives in Hawai'i had extended diplomatic recognition to the Provisional Government, and it was becoming embarrassing that he had not. So on January

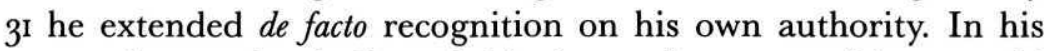
report home, he indicated his hope that recognition would strengthen anti-annexationist feeling in the Islands and would stimulate an abdication by Lili'uokalani in favor of her niece Princess Ka'iulani. He also asked-it was beginning to seem like 
a refrain-for a British warship to be stationed in Hawaiian waters. ${ }^{11}$ The British government approved recognition but saw no reason to send a warship. ${ }^{12}$

Wodehouse's reference to Princess Ka'iulani was an expression of a plan being considered by English residents in Hawai' $i$, headed by Theophilus H. Davies, a businessman and longtime resident, to persuade Lili'uokalani to abdicate in favor of her niece. Ka'iulani, then 17 years of age, was the daughter of Lili'uokalani's younger sister Miriam Likelike and Archibald S. Cleghorn, a Scotsman. Raised with British schoolmasters and at that time completing her education in England, Ka'iulani was considered thoroughly British in her outlook. In late I8gI, she had been designated heir to the throne by the childless Queen. Davies, who was Ka'iulani's mentor and guardian, considered this a fortunate circumstance, and for some time he had been working to make Ka'iulani as British as possible through education. Her claim to the throne was clear, and if Lili'uokalani agreed to abdicate, $\mathrm{Ka}$ 'iulani would become queen, and through her the objects both of increase of British influence and an anti-annexation government policy could be achieved. Davies advanced this idea to the British Foreign Office with Wodehouse's approval. ${ }^{13}$ Many people in Hawai'i, including Dole, would have been satisfied if Ka'iulani had become queen, but it was not a practical idea. The Americans, who had largely engineered the Revolution, were tired of the Monarchy and had previously declared the Monarchy ended. They wanted annexation as a way of ending Hawai'i's constant political squabbling. ${ }^{14}$ Presumably too, these people would not tolerate for long a sovereign with pro-British sympathies, no matter how circumspect she might be about expressing them. On the other hand, the placing of $\mathrm{Ka}$ 'iulani upon the throne would probably have stopped the current moves toward annexation and assured an immediate future of greater Hawaiian openness toward the extension of British interests. The British government neither supported nor discouraged this scenario, but if it had come about the government would probably have been satisfied with it.

Regardless of the strict neutral attitude of the British govern- 
ment, Wodehouse's obvious hostility to the Hawaiian Provisional Government seems to have encouraged Lili'uokalani's supporters and the former Queen herself into believing that the British might be persuaded to support her restoration. On January 3I, Lili'uokalani summoned Wodehouse and gave him a letter to Queen Victoria, asking for her help in getting the British government to support her restoration to the throne. She alluded in this document to her surrender to the rebels as being caused by her desire "to avoid violence and bloodshed, and damage to my subjects." ${ }^{15}$ It was the expression of a theme she would expound upon later. Victoria's reply conveyed her assurances of "our highest consideration and regard" but was not helpful in pledging British support for Lili'uokalani's cause. Instead, she recommended the Hawaiian Monarch "to the protection of the Almighty." 16 The British government did not want to become involved.

During the next few months, two trends became clear. The first was that the Provisional Government was there to stay. The annexation treaty which had been quickly drawn up by a group of haole representatives sent to Washington had been submitted to the Senate by the outgoing Harrison administration, but Grover Cleveland became President before it could be acted upon. He quickly withdrew the treaty from consideration and sent an investigator to Hawai'i to conduct an inquiry into the actions of Stevens in possibly interfering in the Revolution. Thus, the second trend was the growing probability that the United States would not annex the Islands.

As the new situation began to clarify, Great Britain came under increasing criticism from some quarters in the United States and Hawai'i. Wodehouse's nearly constant complaints to the Hawaiian Provisional Government had by now made him fairly unpopular among the government's supporters. His demands that the American naval landing parties be withdrawn was a consistent complaint, as was his request that the American flag, which had been raised over 'Iolani Palace, be taken down. ${ }^{17}$ The status of an American protectorate implied by the flag was improper, and in view of the fact that the ability of the Provisional Government to maintain order was unquestioned, Wodehouse said, it was no 
longer necessary for the American flag to be flown. The flag was removed, not because of Wodehouse, but because the American investigator, Senator James Blount, ordered it to be taken down.

Local criticisms of Wodehouse aside, the mounting attacks on Great Britain from the American press began to cause some concern to British officials. The British Minister in Washington, Lord Pauncefote, noted the increasing criticism and expressed his frustration at the nature of some of it. The New Evening Post, for example, said the British failure to register an immediate protest was "most exasperating." Everyone knew the British wanted to protest. Why didn't they? Were they afraid a British protest would be the quickest way to cause the United States to annex Hawai'i? ${ }^{18}$ Perhaps, said Pauncefote, the British lack of action is confounding those who want annexation quickly. If that were so, the British refusal to take sides and to remain uninvolved was smart strategy from the British point of view.

The official British neutral stance was not reflected in Wodehouse's conduct during the period between the spring of 1893 and the middle of 1894 when the Hawaiian Republic was established. In countless ways, the British Commissioner harassed the Provisional Government, his sally concerning the flying of the American flag over the Palace being typical. On one occasion, he asked that the government sponsor a referendum to give the Hawaiian people an opportunity "to express their sentiments on the question of the annexation of these Islands to the United States of America before any final steps are taken in this matter." 19 An irked Dole replied that he would be happy to receive from the British Government precedents "wherein a similar course has been followed by Her Britannic Majesty's Government in the establishment of territorial jurisdiction over islands in this ocean." 20

Varying his tactics, Wodehouse refused to accept invitations to attend various official functions. One example was an official reception honoring Captain George C. Wiltse, Commander of the U.S.S. Boston, who had ordered the American naval forces ashore during the Revolution. In his report, Wodehouse stated that little notice was taken of this celebration and attendance was very poor. ${ }^{21}$ On the occasion of the celebration of the first anniversary of the Revolution on January 17 , I894, Wodehouse did not 
even reply to an invitation to attend sent by Dole, telling Dole later only that he had been unable to join the observance. ${ }^{22} \mathrm{He}$ also did not attend the ceremonies at the opening of the Constitutional Convention to establish a constitution for the new Hawaiian Republic. ${ }^{23}$

Wodehouse showed his displeasure with the Dole government in other ways. His reports to his government were strongly biased in favor of the Native Hawaiians and the Monarchy. He wrote to Lord Rosebery of his concern over the security measures taken by the Provisional Government and referred several times to the government as "a military despotism." ${ }^{24} \mathrm{He}$ went out of his way to cultivate Senator Blount. Presumably Blount's mission would be of most value to the British government if it led to an American repudiation of the Revolution and a restoration of the Queen, and Wodehouse seems to have done what he could to bring about such an outcome. ${ }^{25}$ As Wodehouse hoped and expected, Blount's report excoriated Stevens and the Hawaiian rebels and recommended the restoration of Lili'uokalani.

To an extent Wodehouse's and the British government's concern in the aftermath of the Hawaiian Revolution was motivated locally by actions taken by the Provisional Government against British citizens in Honolulu for allegedly subversive activities, and nationally by fears that British trade might be adversely affected by an American annexation of the Hawaiian Islands. Concerning the former, Wodehouse remonstrated on behalf of G. C. Kenyon and Percy Gardiner, British citizens who had been arrested for seditious activities involving criticism of the Provisional Government. ${ }^{26}$ Wodehouse also complained about attacks made upon him personally by the Hawaiian Star, a pro-annexation newspaper, and demanded that Dole put a stop to them. ${ }^{27}$ As for the trade problem, the British fears resulted from the knowledge that annexation by the United States would bring U.S.-Hawai'i trade into the realm of the American coastal trade immediately and would thereby prohibit British ships from carrying goods between Hawai'i and the U.S. Mainland. It would be a severe blow, since most Hawaiian raw sugar destined for West Coast refineries was carried in British merchant vessels. ${ }^{28}$ Fortunately, Blount's report together with Cleveland's earlier action meant the 
end of the annexation movement at that time, and the British could breathe a sigh of relief.

\section{Correct but Distant: Relations with the Republic}

Cleveland believed that the United States, by acting against Lili'uokalani, in effect, had a moral obligation to restore her to her throne. His attempt at restoration ran afoul of the Queen's initial determination to punish those who had rebelled against her and ultimately was undone by the unexpected determination of the leaders of the Provisional Government not to accept the restoration of the Monarchy even with the power of the United States thrown against them. Cleveland's unwillingness to use force to bring about a restoration, plus his refusal to accept the opportunity offered to annex Hawai'i, left matters at a stalemate. By early 1894 Dole and the other Provisional Government leaders began to make plans to establish a republic which could function as a viable government until such time as the Americans were willing to accept the gift so freely offered them.

The establishment of the Republic of Hawai'i on July 4, I894 was a stopgap. Internally, dissatisfaction among the Native Hawaiians was assured. A constitutional convention, chosen by an electorate limited mainly to property holders who swore an oath of allegiance to the Provisional Government-a step which most Natives would not take-drew up a constitution which not only set aside the continuation of the Monarchy in any form but also established voting and officeholding qualifications so strict that only a few Natives, and no Orientals, could meet them. It was an oligarchic government which was controlled by the haole, particularly Americans. On the external side, the failure of the annexation movement gave the British some hope that the Islands might somehow remain independent. The hope was not strong, however, except for the immediate future. It appeared more certain than ever that Hawai'i's ultimate destiny lay in becoming a part of the United States. While the American government eschewed possession, it did continue close economic relations with the Republic by passing the Wilson-Gorman Tariff of 1894 , which removed the subsidy paid to domestic sugar producers and 
restored the duty on foreign sugar. Since the U.S.-Hawaiian Reciprocity Treaty was still in effect, Hawaiian sugar did not have to pay the duty. So the sugar industry, the mainstay of Hawai'i's economy, was assured once more of a steady and profitable market. None of this was particularly encouraging to the British government's policy of keeping Hawai'i out of the American orbit as far as possible.

By the time the Republic was established, Wodehouse had clearly become an impediment to the maintenance of good relations between the Republic and Great Britain. Francis M. Hatch, the Minister of Foreign Affairs in the new regime, was convinced that Wodehouse was in league with Lili'uokalani and her followers to restore the Monarchy. It was true that there was a good deal of communication between the former Queen and the British minister, but most of it was instigated by Lili'uokalani. ${ }^{29}$ Wodehouse had been supportive of the Monarchy in the months immediately following the Revolution, but he had come to believe that the Queen should not be supported any longer after she had refused for a time to accede to the American government's request to deal leniently with the rebels as a condition of American support for her restoration. ${ }^{30}$ The view that Wodehouse was working to undermine the Hawaiian government had become widespread, however, and he realized his usefulness was coming to an end. ${ }^{31}$

Wodehouse had other reasons for desiring to be relieved of his duties at this time. He had been in Hawai'i for 15 years without any leave, was not in good health, and wished to return to England to spend his last years. The British government accordingly granted him leave to return to England and began preparations to send a replacement.

Wodehouse's replacement, Albert George Sidney Hawes, was a former Royal Marine officer. After spending I3 years helping to organize a marine component for the Japanese Navy, he had joined the British Foreign Service and had been in several posts in Africa and the Pacific before coming to Hawai'i.

Hawes arrived in Honolulu early in July 1894 . He was almost immediately involved in some difficulties concerning Wodehouse's official position until Wodehouse left Hawai'i for England 
in September. ${ }^{32} \mathrm{He}$ was also much concerned in the question of British recognition of the Hawaiian Republic. Most countries followed the lead of the United States, which recognized the Republic at the end of August, but Hawes believed that President Cleveland's letter to the Hawaiian government did not constitute an official recognition. The British government agreed, thus causing some delay before the British conferred recognition. On November I5 Hawes handed President Dole the affirmation of recognition by Queen Victoria. ${ }^{33}$ Great Britain thus was the last in the list of countries granting diplomatic recognition to the Hawaiian Republic.

During the fall of 1894, the most important diplomatic effort concerning the two countries was the negotiations concerned with the laying of a trans-Pacific cable. The idea of a cable across the Pacific had been around for some time, and in the fall of 1893 the British Colonial Office began working on plans to lay a cable from British Columbia to Australia by way of Hawai'i. The Foreign Office did not support the plan at that time, saying that the Provisional Government was only temporary and that the British government did not consider it to have the authority to negotiate an agreement to cede or lease territory which would be required for a cable station in the Islands. ${ }^{34}$

After it became clear that the United States would not annex Hawai' $i$ and the Hawaiian authorities were moving to establish a republic, the British began to reconsider. In order to promote American support and reduce opposition in Hawai' $i$, the British revised their original plan to include a branch cable to Honolulu. Thus Hawai'i would be connected not only to Canada but also via existing cable lines to the United States. In talks between Lord Pauncefote and Secretary of State Walter Q. Gresham in Washington in March 1894, the American government considered the improvement of communication between Hawai' $i$ and the United States a positive benefit and indicated support for the idea. ${ }^{35}$

Thereafter events moved quickly. The Foreign Office authorized the Canadian Dominion government to send an agent to negotiate a cable agreement with the new Hawaiian Republic on behalf of both the British and Canadian governments. An agreement should include the right to occupy "in perpetuity" an island 
for a cable station. ${ }^{36}$ The agent, Sandford Fleming, arrived in Honolulu on October 6. He and Foreign Minister Hatch entered into negotiation at the Hawaiian Hotel and in less than two weeks had arrived at an agreement. On the day the cable agreement was signed, Hawes wrote jubilantly to the Earl of Rosebery, the Foreign Office Official administering the cable negotiations, announcing success. ${ }^{37}$

Unfortunately, Hawes' announcement was premature. The Hawaiian government wanted a cable, but it preferred an American one. The government's Executive Council did not like the British proposal, which involved a free lease of Necker Island to the British, plus payment of an annual subsidy to the British cable firm. In return, the British would lay a branch cable from Necker to Honolulu. Although the Executive Council signed the agreement, they insisted it could not be implemented until the American government approved, for there was a clause in the Reciprocity Treaty which required American approval before any Hawaiian territory could be transferred or leased to another power. So the Hawaiian authorities used the necessity of American approval as a means of delaying a final favorable outcome to the British cable proposal while they sought to use the threat of a British cable as a means to prod the Americans into developing a plan for an American cable. ${ }^{38}$ As Hatch put it in a letter to the new Hawaiian Minister, Lorrin A. Thurston, "Now that we have got the matter started we can drop the British negotiations, or keep them dormant for the benefit to be obtained from the mere fact of the British application." ${ }^{39}$

It was a clever idea, but it did not bear fruit. The Congress in early January 1895 did not approve President Cleveland's request to allow the British to continue with their cable project, but then it could not agree on what to do about constructing an American cable. There was no agreement on what role the federal government should play in financing, nor on the question of which company-several were formed to secure the cable franchise-would actually be allowed to construct the cable. ${ }^{40}$ By 1897 nothing had been done. After a scare caused by unofficial attempts by a British firm to draw up a contract with the Hawaiian government using Fanning Island as a cable station, a bill was drawn up in Congress 
and eventually passed early in July I898. In the general confusion attending annexation at that time, the bill was voided by failure of the State Department to approve it. Hawai'i had to wait several more years for a cable, which was finally constructed and became operational early in 1903 .

\section{The Royalist Uprising of i895 and its Consequences}

By far the most difficult and long-lived problem the British Government and Hawes had with the Hawaiian Republic was the claims of British citizens arising out of the insurrection of January 1895. This revolt grew out of the refusal of Hawaiian royalists and of Lili'uokalani herself to accept the overthrow of the Monarchy in 1893 as final. Given the dissatisfaction among a large segment of the Native population and the organizing and leadership abilities of Lili'uokalani and some of her adherents, it was practically inevitable that some attempt to reassert monarchist claims would be made once it became certain that the United States would not intervene to restore the Queen to her lost throne and that the revolutionists would move to make their revolution permanent by establishing a republic.

Plotting seems to have begun seriously shortly after the Republic's government was created in July i894. In September, the monarchists made their first move. The Hui Aloha 'Āina, or Hawaiian Patriotic League, sent a petition to the British government on September 22. The petition denounced the actions of the revolutionaries as illegal and appealed "to the wider discretion of the Powers that regulate the affairs of Nations to arbitrate in our cause" to help to restore the Hawaiian Monarchy. ${ }^{41}$ A few days later Herman A. Widemann, a former Cabinet minister and supporter of Lili'uokalani, left Honolulu for Europe to present her case before the European governments. It was a hopeless venture. The United States would not support a restoration of the Monarchy, and all other countries including Great Britain followed the American lead in doing nothing to subvert the Republic, an effective if unpopular government, in favor of the royalist cause. As Hawes noted in a dispatch the day after the petition was sent, it was too late for any action to support the Queen. ${ }^{42}$ 
Widemann made no progress in his mission. He appears to have concentrated on converting the British government, hoping that British support would induce other governments also to support the royalists. But the British would not take even the first step. When he arrived in London, Widemann asked for an interview with Kimberley at the Foreign Office, but it was refused. Kimberley did not even reply directly to Widemann, the reply being sent by a Foreign Office spokesman who said no disrespect was intended toward Lili'uokalani, but the British government desired "to abstain strictly from all interference in the internal politics of Hawaii." ${ }^{43}$ So that was that. The royalists in Hawai'i would get no help from any outside source. They would have to gain their goals by their own efforts.

Now that they had been abandoned by the powers, the next move of the royalists was direct action against the Republic. To some degree this was being considered even before the failure of Widemann's mission to Europe. As early as September, Lili‘uokalani and her followers began to think about forcible action to regain power, and the position of Wodehouse as a confidante of the Queen allowed the British to become aware of the conspiracy long before any other power, or even the Hawaiian government. Now no longer British Minister and awaiting his release to return to England, Wodehouse went to see Lili'uokalani on September I. She told him that "her people were becoming very impatient for a rising" and that plans were already being developed for a rebellion, which she was confident would succeed. She said she would notify the British Minister before the uprising took place. Wodehouse duly reported his conversation to Hawes, who passed it on to Whitehall. ${ }^{44}$ Realizing he might have to act without further authorization from his government, Hawes made arrangements with the captain of the recently-arrived H.M.S. Hyacinth to be prepared to land troops if necessary. ${ }^{45}$

The British were thus well aware of the conspiracy against the Republic and had some knowledge of its leaders and its scope, but nothing was done to warn the Hawaiian authorities.

The police authorities in Honolulu were not kept long in the dark about the conspiracy. ${ }^{46}$ Their own agents were working diligently, and from time to time people were brought in for question- 
ing. Early in December one such group of arrests brought to Hawes' attention the inescapability of British involvement in an uprising. Among those arrested and detained by the Hawaiian police were several British citizens, or people who claimed to be such. Hawes wanted to know what laws they had violated, saying a forthright statement on the matter by the Hawaiian government would serve to calm the fears of British residents. Hatch replied that British citizens had nothing to fear if they were not involved in any plotting against the Republic. ${ }^{47}$

The police activity against the conspirators did not prevent the uprising, but it did force it to expose itself prematurely. When police investigated a report of an arms cache at a house in Waikīkī east of Honolulu early in the morning of January 6, I895, there was shooting and bloodshed. Their hands forced, the rebels began to gather at Diamond Head and other places, and the government called out its armed forces. This is not the place to discuss the January 1895 insurrection in detail, except to note that it was not quickly contained and caused great anxiety among the leaders of the government. On the other hand, even though the main fighting went on for about five days and the main leaders of the revolt were not captured until the 14th, the government had never been in any serious danger. The government had acted quickly both on the military and the behind-the-lines front, not only eventually capturing all those under arms, but also rounding up a number of people suspected of giving support to the rebellion.

The vigor of the government security forces in detaining suspects caused the main difficulties with foreign governments, for many nationals of other countries were among those caught in the net. Hawes' first communication to the Foreign Office on the rebellion noted that several British subjects were among those arrested. He expressed concern that he had not been able to get assurances that capital punishment would not be imposed. ${ }^{48}$

It was the beginning of a long and difficult problem for the British government which would not end until well after annexation of Hawai' $i$ to the United States. Hawes did act immediately to keep the British government from being accused of participation in the uprising. On January 8, Hawes told the Republic's Attorney General, William O. Smith, that one of the accused rebels 
thought to be a British citizen had not sought shelter at the British Consulate, but if he did appear the Attorney General would be notified. ${ }^{49} \mathrm{He}$ also allowed a detachment of soldiers to search the Consulate-a most unusual concession, showing that Hawes was leaning over backward to avoid giving any impression of official British complicity in the insurrection. His actions, together with the fact that there was no British warship in Honolulu Harbor when the rebellion took place-Hyacinth had left two days after Christmas-was generally convincing proof that the British government had not been involved.

But Hawes had an uphill battle to fight. There remained the fact that several British citizens had taken part in the insurrection or had supported it. The annexationists had no difficulty in believing that even if the British government had not been directly involved, that government was undoubtedly disappointed that the rebellion had not succeeded. This might well have been true, for the overthrow of the Republic would probably have led to a restoration of the Monarchy and the end of attempts to bring about Hawai'i's annexation to the United States, at least for the near future. Such a view might also explain why Hawes did not apprise the Hawaiian government of his information about a plot.

Having succeeded in dampening accusations against the British government, Hawes turned to upholding justice for the British citizens accused of participation in the rebellion. At first he was not encouraged. His attempt to get the Hawaiian authorities to agree not to impose any death sentences had failed, and their decision to try the conspirators by a military tribunal instead of in the regular courts caused consternation. The reaction of the British government was spirited. Lord Kimberley told Hawes that he should demand a delay in execution for any Britisher sentenced to death for complicity rather than participation, or for any British participant sentenced to death if he had not received an open and fair trial. Kimberley noted that the American government had given similar instructions to its minister. ${ }^{50}$

The trials of the rebels were held before military courts during the period January 17-30. Many of the defendants were British, or claimed to be. One of Hawes' greatest problems was the sorting out of citizenship; many claiming to be British subjects were later 
found to be naturalized Hawaiian citizens, with no claim to British protection. The greatest difficulty was over the question of "denization," a peculiar arrangement wherein a foreign resident in the Islands could sign papers giving him the right to take part in political affairs-including the right to vote-yet not lose his original citizenship. The Provisional Government had continued the practice but required an oath to support the government. ${ }^{51}$ The alleged violation of that oath was the basis for the Hawaiian government's claim of authority to try foreigners possessing letters of denization who had taken up arms or plotted against the Republic.

It was a complicated issue, too involved to be taken up in detail here. It was time-consuming for Hawes, who spent countless hours, even days, during the trials and long afterwards interviewing prisoners, attending the military trials, examining countless documents, and communicating with his government. ${ }^{52}$ The most critical cases involved those British subjects who were tried and sentenced to death or life imprisonment. The British government, through Hawes, kept a close watch to see to it that all Britishers who were brought to trial received fair trials, ${ }^{53}$ and in nearly every case it was satisfied that justice had been done, restricting its remonstrances mainly to what it considered to be the severity of the sentences. ${ }^{54}$ None of those sentenced to death was executed, and nearly all sentences were commuted within a year or two.

The most annoying cases arising out of the Counterrevolution involved those who were arrested and detained in prison but never brought to trial. A few of these were forcibly expelled from the Islands. These people, mostly Americans and British, brought suit against the Hawaiian government, and in some cases the suits dragged on into the period after the Republic ceased to exist. By the time the suits were seriously under consideration a new British representative was on the scene. In early August of 1897, Hawes died suddenly as a result of complications from a fall on a trip to Hilo, and the new representative, W. J. Kenney, a former consul in Formosa, took up the cases. ${ }^{55}$ By and large the Hawaiian government took the position that since the complainants had not been tried and acquitted there was no liability on the part of 
the government. Kenney indicated that this view could not be accepted by the British government and proposed that the cases be submitted to arbitration "of an independent jurist of high standing." 56 The Hawaiian authorities were obviously pursuing a strategy of delay, for by this time Congress had authorized the annexation of the Hawaiian Islands. The British offer of arbitration would probably have been accepted if not for annexation, but now the whole question left the jurisdiction of the Republic and had to be referred to the government of the United States.

The subsequent history of the claims was long and tangled. At the time annexation took place the Hawaiian authorities told the British that the claims would have to be referred to the United States. In 1899, the British pursued the claims with the American government, and, in 1903 , the Hawaiian territorial government recommended the establishment of a claims commission to deal with the problem, but the British preferred arbitration. Finally, in I910, the two governments signed the Pecuniary Claims Arbitration Agreement to establish an arbitral tribunal. By that time only eight out of the original i3 claimants were still alive. World War I interrupted the activities of the tribunal, which were not resumed until 1920. The last cases were dealt with in i925. On November 10, 1925, the commission ruled in the cases of the five remaining claimants and the heirs or representatives of two other claimants. The claims were rejected on the ground that the Hawaiian Republic no longer existed, and the United States could not be held liable. "The legal unit which did the wrong no longer exists, and legal liability for the wrong has been extinguished with it." ${ }^{57}$

\section{The Transition to Annexation}

Kenney probably did not realize that within a year after taking up his duties in Honolulu, the Hawaiian Republic would be annexed by the United States. He must have been aware, however, that the entire energies of the Republic were dedicated to bringing about annexation, and feeling toward that end was very strong among the American residents. Hawes had noted this activity and had expressed concern that the Hawaiian government showed no interest in listening to Native opposition. He also believed non- 
American foreigners whose interests would be affected by annexation should have a voice. His interest in organizing petitions among British residents, including sugar planters, had not been supported by the British government, which continued to follow a policy of abstention from any interference in Hawaiian affairs. ${ }^{58}$

It was a difficult policy to follow, and questions were asked in London concerning the perceived supineness of the government in the face of the annexation threat. In June i897, questions were asked in the House of Commons about what the British government would do to prevent the Hawaiian Islands, which were so important to British trade and cable communications in the Pacific, from falling into the hands of the United States. The reply was to the effect that the government would act to see that lawful rights of Britain and its subjects would be maintained.$^{59}$ It was not a very helpful statement.

The British were not the only ones concerned about annexation. Toward the end of 1897 the German ambassador in London, Count Hatzfeldt, spoke to Salisbury about his government's concern and stated that if the United States moved to annex Hawai ' $i$, the British and Germans should jointly propose to get a share in the administration of Hawaiian affairs or else an American withdrawal from the three-way administration of Samoa in exchange for a clear American title to Hawai'i. Salisbury was interested in this unofficial German proposal but did not believe the Americans would agree. The Colonial Office, to whom the matter was referred, thought the proposal interesting but saw little gain for Britain in Samoa. ${ }^{60}$ It might simply clear the way for a complete German takeover of Samoa. Thus advised, Salisbury decided not to join Germany in a statement, and he communicated this decision to the ambassador in Berlin. ${ }^{61}$

The 1896 election brought a major change in the annexation picture. With Cleveland in the White House the British did not have to worry about Hawaiian annexation, but the new Republican administration reviewed the annexation question. At first McKinley's intentions regarding annexation were not clear, and opponents of annexation comforted themselves briefly with the recollection that this was the same William McKinley who as a senator had helped author the I8go tariff which had caused such 
disruption to the sugar trade in the last years before the Hawaiian Revolution.

The ambiguities concerning McKinley did not last long. In the spring of 1897 , State Department officials and a special Hawaiian commission began negotiations on a new annexation treaty. Signed in June, this treaty differed but little from the one negotiated in 1893 . In the Senate, however, the treaty became bogged down. ${ }^{62}$ By early 1898 it had not been acted upon, and the furor over the destruction of the Maine in Havana harbor in mid-February caused the treaty to be forgotten as the United States moved toward war against Spain. The British could breathe more easily again.

The failure of the Senate to act upon the annexation treaty encouraged the Native Hawaiians to hope for the continued independence of their Islands. Amidst the talk in Honolulu of what failure of the treaty could mean for Hawai'i's future, a view was advanced which stirred controversy and brought up questions about British designs on the Islands. On March I, the Hawaiian Gazette published an open letter to the Hawaiian people by Theo H. Davies, the British businessman who as Princess Ka'iulani's guardian had tried to bring her to the Hawaiian throne to preserve the Monarchy. He said that if the United States did not annex Hawai'i the Native Hawaiians would have to face a situation in which the Hawaiian Republic would endure. The essence of his plea was that the Hawaiians should accept the fact that the Monarchy was dead and that they should now support the Republic. In return, Davies said, the Hawaiians had a right to expect to be allowed a greater role in the government and an extension of the franchise.

Davies' comments stirred up a small storm of indignation in most of the English language press. The Gazette commented that Davies' proposal would give political power back to the Natives. The newspaper added that Davies' assumption that the Natives would line up with the whites to promote good government was probably wrong, and that the history of the Monarchy showed that a Native-dominated government would be a disaster. ${ }^{63}$ The idea that the British were working to bring back the Monarchy took hold and was quickly taken up and spread abroad. In a 
report to the Foreign Office, Lord Pauncefote noted that the Senate Committee on Foreign Relations' report on the annexation treaty accused Great Britain of scheming to restore the Hawaiian Monarchy and thereby to prevent annexation. Pauncefote stated to the American government that there was "no ground whatever for the allegations contained in this Report as to the attitude of Great Britain respecting Hawaii." 64

Pauncefote may well have been correct, since the diplomatic correspondence of the Foreign Office shows no indication of a British effort to restore the Monarchy. It is likely that whatever it might have been considering in the aftermath of the coup of January 1893, Lili'uokalani's own unforgiving attitude and the unsuccessful I895 uprising had convinced the British government that the Monarchy was beyond any hope of resurrection.

The curtain was raised on the last act of the annexation drama by the outbreak of the Spanish-American War. Commodore George Dewey's victory at Manila Bay and the subsequent sending of an American Army across the Pacific to capture Manila impressed the strategic importance of Hawai' $i$ to trans-Pacific communications upon Congress and the American public, and a congressional joint resolution for annexation was quickly drawn up and steered through Congress. On August 12, 1898, in a ceremony in front of 'Iolani Palace at which the former Hawaiian royalty and practically all Native Hawaiians were conspicuous by their absence, the Hawaiian flag was lowered for the last time and the American flag raised, this time permanently.

There was nothing left for the British to do but to complain mildly about the poor economic situation in the Islands, the obvious unpopularity of annexation among the Natives, and the concern expressed about the form of government which would be established in the new possession. Kenney pointed to local concern that all the main government posts would be filled by Mainlanders, and he noted that the large debt of the Republic would make it difficult to deal with the claims of Britishers arising out of the 1895 insurrection. ${ }^{65}$

As far as Great Britain was concerned, the long struggle to keep Hawai' $i$ out of the clutches of the United States was over and had ended in defeat. The futility of the struggle had been practically 
certain since the coming into effect of the Reciprocity Treaty of I875 and was a foregone conclusion once the Hawaiian Monarchy was overthrown. After 1893 , the one forlorn chance to turn the course of destiny around was the 1895 insurrection, which, if successful, would have restored the Monarchy and would at least have bought time for the British to try to find some way to preserve Hawai'i's independence. The time bought, however, probably would have done no more than delay annexation to the United States.

So the deed was done, and annexation was finally accomplished. The British government preferred not to dwell upon the fact, however, and comforted itself by officially pretending that nothing had really happened. When the Colonial Office referred a question from the Hong Kong government as to whether the annexation of the Hawaiian Islands had been recognized by the British government, the Foreign Office replied: "H. M. Government recognize the annexation of these islands as having taken place, although no official communication formally recording the fact has passed between H. M. Government and the government of the United States." 66

\section{Notes}

${ }^{1}$ The best account of the first years of Kalākaua's reign and the growth of dissension under Gibson's leadership is Ralph S. Kuykendall, The Hawaiian Kingdom, vol. 3, The Kalakaua Dynasty (Honolulu, U of Hawaii P, 1967). For a closer look at the events from 1882 to 1887 , see Ernest Andrade, Jr., "The Hawaiian Revolution of 1887 ,' master's thesis, U of Hawai'i, 1954.

2 John Hay Wodehouse, despatch to R. Adm. Sir Michael Seymour, 7 June 1887, cited in Wodehouse, despatch to Lord Salisbury, 2 Aug. 1887, Foreign Office file 58/220, Public Record Office, Kew, England: hereafter referred to as FO.

${ }^{3}$ Wodehouse, despatch to Lord to Salisbury, 2 Aug. 1889, FO 534/42. It has never been known for certain if Wilcox was just trying to establish a new constitution or if he was also intending to replace Kalākaua with his sister Lili'uokalani. Wodehouse believed Lili‘uokalani was aware of the plot and was ready to take her brother's place as sovereign.

${ }^{4}$ Wodehouse, despatch to Salisbury. 2 Aug. 1889, FO 534/42.

${ }^{5}$ Wodehouse, despatch to Lord Rosebery, 22 Sept. 1892, FO 534/55.

${ }^{6}$ Wodehouse, despatches to Rosebery, 20 Oct. and 2 Nov. 1892, FO 534/55. See also comments of Theo H. Davies in $H G, 5$ Nov. 1892 . 
7 Wodehouse, despatch to Rosebery, 12 Oct. 1892, FO 534/55.

${ }^{8}$ Wodehouse, despatch to Rosebery, 18 Jan. 1893, FO 534/59.

${ }^{9}$ Wodehouse, letter to Sanford B. Dole, 30 Jan. 1893, Foreign Officers in Hawaii-British Legation $1888-1900$, FO \& EX, AH.

${ }^{10}$ Dole, letter to Wodehouse, 3I Jan. 1893, FO \& Ex.

${ }_{11}$ Wodehouse, despatch to Rosebery, 31 Jan. 1893, FO 534/59.

12 Rosebery, despatch to Wodehouse, ro Feb. 1893, FO 534/59.

${ }_{13}$ Theo H. Davies, letter to Rosebery, $3^{1}$ Jan. ${ }^{8} 893$, FO 534/59.

${ }^{14}$ Kuykendall, Hawaiian Kingdom 3:596 and 618.

${ }^{15}$ Enclosure in Wodehouse, despatch to Rosebery, I Feb. 1893, FO 534/59. The original document, undated, is in $\mathrm{FO} 58 / 270: 4 \mathrm{I}^{-2}$.

${ }^{16}$ Queen Victoria, letter to Lili'uokalani, 8 Mar. 1893, enclosure in Rosebery, despatch to Wodehouse, 9 Mar. 1893 , FO 534/59.

17 Wodehouse, letter to Dole, 3 Feb. 1893, FO \& Ex. Wodehouse's statement that the local government was obviously capable of maintaining order was his first statement along this line and must have been a difficult admission for him to make.

${ }^{18}$ New York Evening Post, I Feb. 1893, enclosure in Lord Pauncefote, despatch to Rosebery, 7 Feb. 1893, FO 534/59.

${ }^{19}$ Wodehouse, letter to Dole, 27 Feb. 1893 , FO \& Ex.

${ }^{20}$ Dole, letter to Wodehouse, $28 \mathrm{Feb}$. I893, enclosure in Wodehouse, despatch to Rosebery, 9 Apr. 1893 , FO 534/59.

${ }^{21}$ Wodehouse, despatch to Rosebery, I Mar. 1893, FO 534/59. The account of the reception by the $D B$, a Honolulu newspaper generally critical of the Provisional Government, differs significantly from Wodehouse's report. $D B, 25$ Feb. 1893, told of a large audience which crowded Arion Hall.

${ }^{22}$ Dole, letter to Wodehouse, 13 and 23 Jan. 1894; Wodehouse, letter to Dole, 24 Jan. 1894, FO \& Ex. 1893.

${ }^{23}$ Wodehouse, letter to Dole, 30 May 1894, FO \& Ex. 1893.

${ }^{24}$ Wodehouse, despatch to Rosebery, I9 July I893, FO $34 / 60$; also io May I893, FO $534 / 59$.

${ }^{25}$ Wodehouse, despatch to Rosebery, I6 Aug. I893, FO 534/6o; Kuykendall, Hawaiian Kingdom 3:627-28. The British government must have been pleased, for it approved Wodehouse's actions. Rosebery, despatch to Wodehouse, 23 Oct. 1893 , FO 534/6o.

${ }^{26}$ Wodehouse, two letters to Dole, 26 May i893; Dole, letter to Wodehouse, 26 May 1893, FO \& Ex.

${ }^{27}$ Wodehouse, letter to Dole, 23 Oct. 1893; Dole, letter to Wodehouse, 27 Oct. 1893, FO \& Ex.

${ }^{28}$ Pauncefote, despatch to Rosebery, I7 Feb. I893; Chamber of Shipping U.K., despatch to Rosebery, 23 Feb. 1893, FO $534 / 65$.

${ }^{29}$ Consider, for example, her letter of protest against the Provisional Government and its plans to set up a Republic and her hopes for support from the British government: Lili'uokalani, letter to Wodehouse, 20 June 1894 , FO 331/2:7-10. 


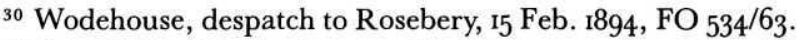

${ }^{31}$ Francis M. Hatch, letter to Wodehouse, 20 June 1894 ; Wodehouse, letter to Hatch, 2I June 1894, FO \& Ex; editorial critical of Wodehouse in PCA, i8 June 1894; Davies, letter to Foreign Office, Ir May I894, FO 534/63.

32 The Hawaiian government's enmity toward Wodehouse lasted for some time even after his departure. In February i895, Wodehouse's son Ernest, who had remained in Hawai' $i$ because of his marriage to the daughter of a local family, was dismissed from his position as Superintendent of the Hawaiian Postal Savings Bank. The government thought he had not been conspicuous enough "in the support of the government" during the uprising of January 1895 . Albert G. S. Hawes, despatch to Kimberley, 8 May 1895, FO 534/67.

${ }^{33}$ Hawes, despatch to Kimberley, 2 Sept. 1894; Foreign Office, despatch to Hawes, 1o Oct. 1894; Hawes, despatch to Kimberley, 20 Nov. 1894, FO 534/64.

${ }^{34}$ Foreign Office, memo to Colonial Office, 25 Nov. $1893, \mathrm{FO}_{33 \mathrm{I}} / 6$.

${ }^{35}$ Pauncefote, despatch to Kimberley, i3 Mar. 1894, FO 331/6.

${ }^{36}$ Rosebery, despatch to Hawes, 31 Aug. 1894, FO 58/282.

${ }^{37}$ Hawes, despatch to Rosebery, 17 Oct. 1894, FO 58/282.

${ }^{38}$ William A. Russ, Jr., The Hawaiian Republic (1894-98) and Its Struggle to Win Annexation (Selingsgrove, PA: Susquehanna U P, 196I) 254. This work contains an account of the British efforts concerning a cable, though not from British sources. It is very detailed on the American and Hawaiian side of the cable problem.

${ }^{39}$ Quoted in Russ, Hawaiian Republic 257.

${ }^{40}$ The legislative effort is extensively treated in Russ, Hawaiian Republic 256-74. Other works dealing with the cable question are: Phillip E. Koerper, "Cable Imbroglio in the Pacific: Great Britain, the United States and Hawaii," HJH I9 (1975): I14-20; Pauline N. King, "Hawaii's Part in Attempts to Build a Trans-Pacific Cable, $1893-1898$," master's thesis, U of Hawai' $i$, 1965.

${ }^{41}$ Enclosure in Hawes, despatch to Kimberley, ${ }_{4}$ Sept. I894, FO 534/64.

${ }^{42}$ Hawes, despatch to Kimberley, i5 Sept. 1894, FO 534/64.

${ }^{43}$ Herman A. Widemann, letter to Kimberley, 24 Oct. 1894; Foreign Office, letter to Widemann, i Nov. I894, FO 534/64.

${ }^{44}$ Hawes, despatch to Kimberley, 4 Sept. 1894, FO 534/64.

${ }^{45}$ Hawes, despatch to Foreign Office, 22 Sept. 1894, FO 534/64.

46 The conspiracy was not a well kept secret. The $P C A$ reported that a meeting to plan a revolt had taken place on Sept. I: $P C A$, I7 Nov. and 17 Dec. 1894 .

${ }^{47}$ Hawes, letter to Hatch, 17 Dec. 1894; Hatch, letter to Hawes, 18 Dec. 1894, FO \& Ex.

${ }^{48}$ Hawes, despatch to Kimberly, io Jan. $1895, \mathrm{FO}_{534} / 67$.

${ }^{49}$ Hatch, letter to William O. Smith, 8 Jan. 1895 British Commissioner, FO $\&$ Ex.

${ }^{50}$ Kimberley, letter to Hawes, 9 Feb. 1895, FO 534/67; Hawes, letter to Hatch, 2I Feb. 1895, FO \& Ex.

${ }^{51}$ A good discussion of the denization practice and its difficulties is in Russ, Hawaiian Republic. 
${ }^{52}$ Russ, Hawaiian Republic, and Albertine Loomis, For Whom Are the Stars? (Honolulu: U of Hawaii P, I976), are the only secondary works which discuss the uprising of 1895 and the subsequent trials, and neither treats the British side of the picture adequately. The major primary materials are the Filibuster file and British Commissioner, FO \& Ex. 1895, AH, and the pertinent Foreign Office documents, mainly FO $534 / 67$ and FO $534 / 68$ in the British Public Record Office. The diplomatic correspondence was published by the Hawaiian Department of Foreign Affairs under the title, Correspondence Between the Government of the Republic of Hawaii and Her Britannic Majesty's Government in Relation to the Claims of Certain British Subjects Arrested for Complicity in the Insurrection of 1895 in the Hawaiian Islands (Honolulu, 1899).

${ }^{53}$ Note especially Hawes, despatch to Kimberley, 30 Jan. and 7 Mar. I895, FO $534 / 67$.

${ }^{54}$ Law Officers of the Crown, despatch to Salisbury, 5 July 1895, FO 534/68. The substance of this ruling was relayed to Hawes in Salisbury, despatch to Hawes, 12 July 1895 , FO 534/68.

${ }^{55}$ An editorial announcing Hawes' death and recapitulating his career said, "During the period when there was friction in the adjustment of our new political system, he did not increase it, and looking somewhat into the future, never attempted to change conditions": PCA, 9 Aug. 1897.

${ }^{56}$ Henry E. Cooper, letter to W. J. Kenney, I Feb. I898; Kenney, letter to Cooper, 5 July 1898 , FO 331/52; also British Legation, FO \& EX. Cooper, Hawaiian Secretary of Foreign Affairs, did admit Hawai'i's liability in one case at the end of 1897 and recommended a damage payment of \$650: Cooper, letter to Kenney, 17 Dec. 1897, British Legation, FO \& Ex.

${ }^{57}$ Fred K. Nielson, American and British Claims Arbitration Under the Special Agreement Concluded Between the United States and Great Britain, August 18, 1910 (Washington, D.C., GPO 1926).

${ }^{58}$ Hawes, despatch to Salisbury, 23 Nov. 1896; Salisbury, despatch to Hawes, $3^{1}$ Dec. 1896, FO 534/72.

${ }^{59}$ Reply of Foreign Office, 24 June 1897, FO 534/75.

${ }^{60}$ Salisbury, despatch to Sir F. Lascelles, 18 Aug. 1897; Colonial Office, memo to Foreign Office, ${ }_{24}$ Aug. 1897, FO 534/76.

${ }^{61}$ Salisbury, despatch to Viscount Gough, 24 Nov. 1897, FO 534/76.

${ }^{62}$ Russ, Hawaiian Republic, chap. 5, has a detailed exposition of the fight for the treaty in the Senate.

${ }^{63} H G$, I Mar. 1898 .

${ }^{64}$ Pauncefote, despatch to Salisbury, 22 Mar. 1898, FO 534/79. The Gazette referred to the Senate report as "rubbish": $H G$, 12 Apr. 1898 .

${ }^{65}$ Kenney, despatch to Salisbury, 29 July 1898 , FO $534 / 80$.

${ }^{66}$ Foreign Office, memo to Colonial Office, $3^{1}$ May 1899, FO 534/83. 